\section{Contextual and individual factors associated with dissatisfaction with the Brazilian Unified National Health System, 2011-2012}

\author{
Fatores contextuais e individuais associados à \\ insatisfação com o Sistema Único de Saúde, \\ 2011-2012
}

\author{
Factores contextuales e individuales asociados a \\ la insatisfacción con el Sistema Único de Salud \\ brasileño, 2011-2012
}

Lúcia Gimenes Passero 1 Jessye Melgarejo do Amaral Giordani 1 Fernando Neves Hugo 2 Vanessa Bielefeldt Leotti Torman 1,3 Suzi Alves Camey 1,3 Juliana Balbinot Hilgert 1

\begin{abstract}
User satisfaction is known to be related to quality of healthcare. The aim of this study was to evaluate the influence of contextual and individual factors associated with user dissatisfaction with the Brazilian Unified National Health System (SUS). This was a cross-sectional multilevel study. Data were collected via telephone by the ombudsman's office of the SUS. Telephone numbers were randomly selected from a telephone company database. Health services, socioeconomic, and individual demographic variables were evaluated, in addition to information on the municipalities. The outcome variable was dissatisfaction with the SUS. Hierarchical multilevel logistic regression was used, and 18,673 individuals were contacted. Prevalence of dissatisfaction was 63.4\% (95\%CI: 62.7-64.1). Unmet demand $(O R=3.66)$, waiting time $>4$ hours $(O R=2.82)$, and number of Primary Healthcare Units $(O R=0.89)$ were associated statistically with dissatisfaction. Characteristics of the health teams' work process showed a strong association with dissatisfaction.
\end{abstract}

Multilevel Analysis; Consumer Behavior; Health Services
1 Programa de Pósgraduação em Epidemiologia Universidade Federal do Rio Grande do Sul, Porto Alegre, Brasil.

2 Programa de Pós-graduação em Odontologia

Universidade Federal do Rio Grande do Sul, Porto Alegre, Brasil.

3 Departamento de

Estatística, Universidade

Federal do Rio Grande do Sul. Porto Alegre, Brasil.

\author{
Correspondence \\ J. M. A. Giordan \\ Programa de Pós-graduação \\ em Epidemiologia, \\ Universidade Federal do Rio \\ Grande do Sul. \\ Rua Ramiro Barcelos 2400 , \\ 2 o andar, Porto Alegre, RS \\ 90035-003, Brasil. \\ jessyesm@hotmail.com
}




\section{Introduction}

The Brazilian Unified National Health System (SUS) is Brazil's national healthcare system, founded in 1988 during a historical moment of re-democratization following 20 years of military dictatorship. The SUS was modelled on the principles of universality, comprehensiveness, and equity, in addition to regional and hierarchical organization and citizens' participation. The basis for the SUS is the 1988 Federal Constitution. Despite major strides, the system still faces challenges for its full implementation 1,2,3,4. Aligned with the fundamentals of primary healthcare, Family Health is the main strategy for changing the country's hegemonic healthcare model. Established in the mid-1990s, the Family Health Strategy (FHS) has brought services to previously underserved communities and territories and has thus been instrumental in improving some key indicators 5,6,7,8.

Since 2003, the SUS has an ombudsman's office with the responsibility of receiving complaints, requests, questions, suggestions, and compliments from users by telephone, letter, e-mail, or direct personal contact. The department ensures ethics, privacy, and confidentiality, serving as a democratic channel for stimulating social participation, disseminating health information, and mediating between citizens and administrators, supporting users by producing information for decision-making and strategies for health services planning 9,10.

It is thus essential that users' opinions of the SUS are included in the evaluation of health services, besides serving as an important dimension in the principle of social participation. Furthermore, user satisfaction is known to be sensitive to quality of healthcare and is associated with greater use and appropriateness of services, stronger bonds between patients and healthcare staff, and better treatment adherence 11,12,13.

The aim of this study was to evaluate the influence of contextual and individual factors associated with users' dissatisfaction regarding the SUS.

\section{Material and methods}

This cross-sectional study is part of a national research project developed by the Brazilian government, aimed at evaluating satisfaction with the SUS (SUS-Satisfaction Study). Data were collected by the ombudsman's office via telephone contact from June 2011 to January 2012. Telephone numbers from the Oi Company were used (responsible for the ombudsman service at the time of the survey), plus the ombudsman office's own data, including fixed and mobile telephones. According to the Brazilian National Household Budget Survey (PNAD 2012), 91.2\% of Brazilian households had access to hardline and/or mobile telephony. By 2013 the proportion had increased to $92.5 \%$. The Central had the highest proportion of households with mobile telephony (94.7\%), followed by the South (92\%), Southeast (91.7\%), North (85.5\%), and Northeast $(85.2 \%)$. Hardline and mobile phone numbers were randomly selected.

Inclusion criteria were age 16 years or older or having a dependent under 16 years of age and use of the SUS in the previous 12 months for at least one of the following: vaccination, laboratory tests, emergency care, and dispensing medication (Figure 1). The sample size for the SUS-Satisfaction Study used the classic formula $S=\left(Z^{*} Z\right)$ * $(\mathrm{P} *(1-\mathrm{P})) /(\mathrm{D} * \mathrm{D})$, where $\mathrm{S}=$ sample size; $\mathrm{Z}$ = value of the normal distribution for a given confidence level (in this case, 1.96 for $95 \%$ confidence interval); $\mathrm{P}$ = expected percentage of the event in the population, and $\mathrm{D}=$ sampling error. The formula was adjusted by population size using the following formula $\mathrm{S}=\mathrm{S} /$ ( $1+(\mathrm{S} /$ population $)$ The sample size was calculated according to the percentage of unknown responses (P), and 50\% was used to result in a larger sample. For each municipality, the results for all respondents used a $95 \%$ confidence interval and 5\% sampling error. All state capitals plus the Federal District ( $\mathrm{n}=$ 27) and all municipalities with more than 500,000 inhabitants $(\mathrm{n}=18)$ were included, plus a simple random sample of non-state capital municipalities with fewer than 500,000 inhabitants each $(\mathrm{n}=16)$. For the other territories (major geographic regions, states, and Brazil), the sample size (sum of samples from each municipality) adopted a $95 \%$ confidence interval $(95 \% \mathrm{CI})$ and sampling error of $\leq 5 \%$.

The outcome variable was dissatisfaction with the SUS, as measured by the following question: how would you rate the SUS overall? The response options were grouped dichotomously as: 1 - very bad, bad, or fair and 2 - good or very good, where option 1 was defined as dissatisfaction with the SUS.

Data from the 61 municipalities were used to compose contextual variables. These contextual data (municipal) were organized into the following dimensions: demographic structure; public investment in social areas; economic conditions; level of development; public health structure; family health coverage; health system outcomes. The data sources were the United Nations Development Program (UNDP. http:// www.pnud.org.br, accessed on 30/Jun/2013), 


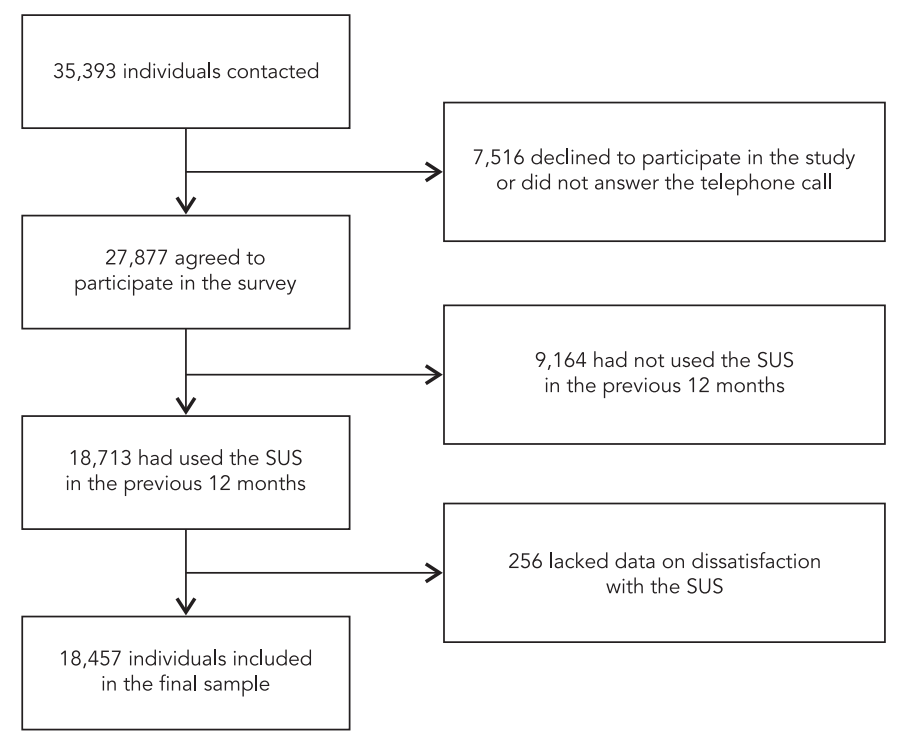

SUS: Brazilian Unified National Health System.

Brazilian Institute of Geography and Statistics (IBGE. http://www.ibge.gov.br, accessed on 30/ Jun/2013), and Brazilian Health Informatics Department (DATASUS. http://wwwdatasus.saude. gov.br, accessed on 30/Jun/2013).

The independent contextual variables were: population density (inhabitants $/ \mathrm{km}^{2}, 2010$ ), number of schools (per 1,000 inhabitants, 2010), literacy rate (in individuals $\geq 15$ years of age, 2010), per capita income (in EUR, 2010), poverty rate (2003), number of healthcare establishments (per 1,000 inhabitants, 2010), number of Primary Healthcare Units (per 100,000 inhabitants, 2012), percentage of healthcare establishments affiliated with the SUS (as a percentage of the total number of healthcare establishments, 2009), percentage of population covered by community health workers (CHW) (2010), percentage of population covered by family health teams (FHT) (2010), percentage of population covered by dental health teams (DHT) (2010), life expectancy at birth (years, 2009), and infant mortality rate (2010). The study also used the Human Development Index (HDI) for the year 2000 multiplied by 100 . The study used the Gini coefficient, which measures the degree of income concentration in a population by comparing the difference in income between the richest and the poorest, with values from zero to one hundred; municipalities with the highest income inequality had values closest to zero. The study also used a SUS Performance Index (IDSUS, 2010), a summary performance indicator for the SUS regarding access obtained and the effectiveness of primary, outpatient, and hospital/emergency care.

The independent individual socioeconomic and demographic variables were: gender (female/male), age in years (16-20, 21-30, 31-40, 41$50,51-60, \geq 60$ ), ethnicity (white/non-white), total household income (< EUR 178.00, EUR 178.00356.00, > EUR 356.00), and education (illiterate, literate, 9 years of school, 12 years of school, $\geq 16$ years of school). Individual health services variables were: waiting time in hours (how long did you wait to be treated at the health service?); case resolution (was your demand at the health service: met, partially met, not met?); and to evaluate if the user had been seen by professionals of the FHS in a unit near his/her residence: were you seen by a Family Health Team near your home? (yes/no).

To organize and compose the analytical design, we used a theoretical model for dissatisfaction with the SUS, based on Andersen 14 (Figure 2). Two levels (individual and contextual) were 
Theoretical model for dissatisfaction with the Brazilian Unified National Health System (SUS), according to individual and contextual variables.

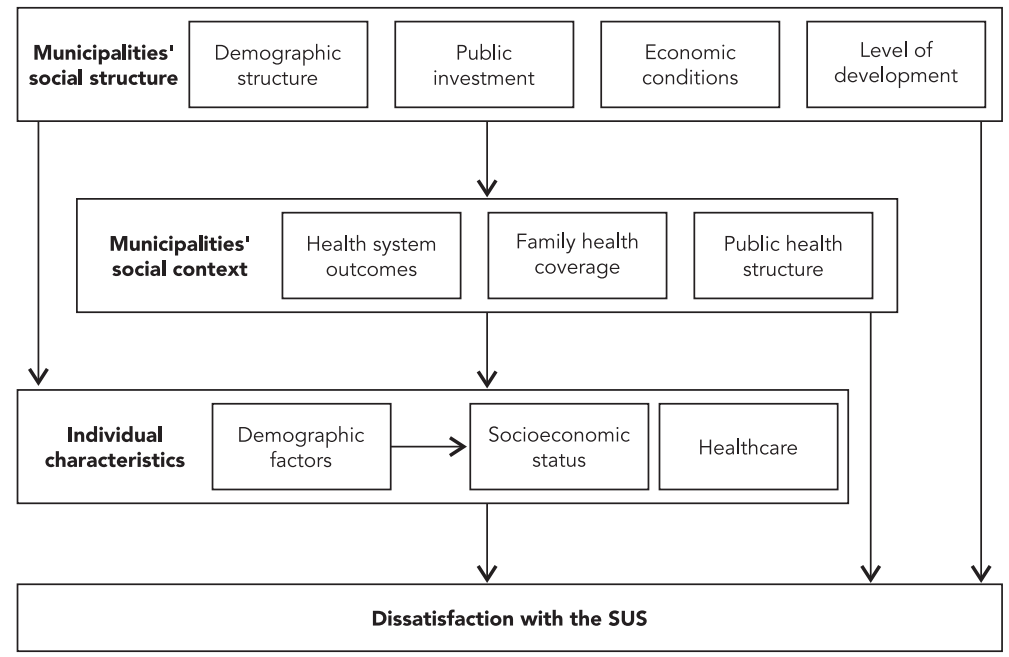

hierarchically structured in associated blocks using the independent variables such as (i) social structure; (ii) social context; (iii) individual demographic characteristics; and (iv) individual health services characteristics. The analytical complexity required in order to understand user dissatisfaction justifies the construction of a hierarchical model to evaluate whether a relationship is direct or mediated by other factors, level of data aggregation, and strength of association between the independent and dependent variables.

The study analyzed absolute and relative frequencies for individuals and municipalities, as well as the outcome variable, presented as proportions and means with the respective 95\%CI. These analyses used IBM SPSS version 18.0 (IBM Corp., Armonk, U.S.A.). To test the effect of different variables on dissatisfaction with the SUS, we used multilevel logistic random effects regression with a hierarchical approach, as proposed by Victora et al. 15. Initially, a model was developed with all of the social structure variables. Variables with $\mathrm{p}<0.20$ proceeded to the next stage, where the variables of the next hierarchical level (social context) were inserted. Variables from the subsequent blocks were added to compose the multivariate models, according to the proposed theoretical model. Random coefficient models were also tested, but with no statistical significance in the assumptions for the components of variance tests. The intraclass correlation coefficient was calculated as defined by Snijders \& Bosker 16. SAS PROC GLIMMIX 9.3 (SAS Inst., Cary, U.S.A.) was used to adjust the multilevel models.

The study used secondary data from the SUSSatisfaction Study of the Brazilian government. According to the Brazilian National Health Council, satisfaction surveys do not require ethical approval; nevertheless, the project was submitted to and approved by the Ethics Research Board of the Federal University of Rio Grande do Sul (UFRGS).

\section{Results}

A total of 35,393 individuals were contacted, of whom 7,516 declined to participate in the survey or did not answer the telephone call, 9,164 were excluded because they had not used the SUS in the previous 12 months, and 256 were excluded because they lacked information on dissatisfaction with the SUS (missing data) (Figure 1). The final sample thus included 18,457 individuals from 61 municipalities.

Prevalence of dissatisfaction with the SUS was $63.4 \%$ (95\%CI: 62.7-64.1). Before dichotomization of the outcome, the 18,457 individuals showed the following distribution: very good 
(7.5\%), good (29.1\%), fair $(34.4 \%)$, bad $(13.8 \%)$, and very bad (15.2\%).

Regarding the sample's characteristics, the majority were women $(67.7 \%), 21$ to 40 years of age $(53 \%)$, non-white $(58.5 \%)$, with family income from EUR 178.00 to 356.00 (71.5\%), and with 12 to 16 years of schooling (53.2\%); $60.5 \%$ of the sample had their demands resolved, $56.9 \%$ reported waiting time up to 1 hour, and $57.7 \%$ had been treated by a Family Health Team at the healthcare unit near their place of residence (Table 1). The 61 municipalities showed the following means and standard deviations for independent contextual variables: HDI $0.79( \pm 0.05)$; Gini index 0.45 ( \pm 0.04$)$; literacy rate $83.1 \%$ ( \pm $5.3 \%)$; poverty rate $36.7 \%$ ( $\pm 14.8 \%)$; life expectancy at birth 69.4 years $( \pm 2.9)$; infant mortality rate $14.7 / 1,000$ live births $( \pm 3.5)$; FHT coverage $47.6 \%$ ( $\pm 28.2 \%$ ); CHW coverage $60.2 \%$ ( $\pm 31.1 \%$ ); and coverage by DHT $27.3 \%$ ( $\pm 27.7 \%$ ) (Table 2 ).

After adjusting for demographic, economic, social, and health services variables (final multilevel model, Table 3), having an unresolved demand increased by 2.66 the odds of dissatisfaction with the SUS when compared to resolved demand; waiting time greater than 4 hours increased by 1.82 the odds of dissatisfaction with the SUS when compared to waiting time of 30 minutes; age 21 to 30 years increased by 0.5 the odds of dissatisfaction with the SUS when compared to age greater than 60 years; and FHT far from the individual's place of residence increased by 0.47 the odds of dissatisfaction with the SUS when compared to individuals with a FHT near their residence. Concerning contextual factors, dissatisfaction with the SUS decreased by $11 \%$ for each increase of one primary healthcare unit, $5 \%$ for each unit of the human development index (HDI), and $11 \%$ for each unit increase in per capita income; and dissatisfaction with the SUS increased by $7 \%$ for each unit in the literacy rate.

\section{Discussion}

This was the first study with a nationally representative sample of users of SUS, conducted by the system's ombudsman's office. The study showed a significant level of dissatisfaction with the SUS and related characteristics of individuals and municipalities, thereby expanding our understanding of this outcome. Dissatisfaction appeared to be associated with the individual variables age, higher education, unresolved demand, treatment by a FHT located far from the individual's residence, and longer waiting time and the contextual variables low per capita income, fewer primary healthcare units per capita, and higher literacy rate. Since user satisfaction is sensitive to quality of care, related to adequacy in the use of services, and has the capacity to serve as a powerful tool for social and community participation $11,17,18,19,20$, the findings obtained in this cross-sectional study are relevant because they allow administrators and health professionals to develop strategies to improve quality in SUS services.

Income is one of the most important social determinants of health and is written into the Brazilian Constitution as one of the components in the definition of health. Per capita income represents societal purchasing power and access to goods and services that are important for health, thus contributing to the municipal health system and becoming a contextual parameter for dissatisfaction. A previous study showed an association between per capita income and greater access to healthcare services 21 , and this may have contributed to users of municipalities with higher per capita income being more satisfied with the SUS than those living in municipalities with lower income. Interestingly, as in other studies, the individual income pattern had an inverse effect on user dissatisfaction. Higher-income individuals tend to have higher expectations of services and thus may be more apt to feel frustrated, thereby increasing dissatisfaction 20 .

Higher literacy rate also proved to be a risk factor for dissatisfaction with the SUS. Adjusting the model for all individual variables and the social context variables related to health services, municipal investment in literacy has a negative effect on satisfaction with health services, adding value to the known relationship between literacy and contextual variables related to use of health services. This relationship probably relates to the fact that people with more schooling tend to obtain better jobs and achieve greater financial and emotional stability (other social determinants importantly related to higher expectations towards services in general) 21.

Age and education are classically associated with satisfaction with health services, and this study corroborated previous findings: higher age and lower education were associated with higher user satisfaction with the health system $11,18,21,22,23$. The main reason for lower prevalence of dissatisfaction among the elderly involves lower expectations and greater resignation in relation to all aspects of life, including health services $11,20,21,22,23$. Dissatisfaction of younger individuals relates to difficulty in access and linkage between users and health teams, since many healthcare services operate during business hours, when the younger population is working or studying 20 . In relation to education, as the number of years 
Sample characteristics and prevalence of dissatisfaction with the Brazilian Unified National Health System (SUS), according to individual level variables, Brazil, 2012.

\begin{tabular}{|c|c|c|}
\hline Dimension/Variables & n (\%) & $\begin{array}{l}\text { Prevalence of dissatisfaction with SUS } \\
\qquad(95 \% \mathrm{Cl})\end{array}$ \\
\hline \multicolumn{3}{|l|}{ Demographic } \\
\hline \multicolumn{3}{|l|}{ Gender } \\
\hline Female & $12,320(67.7)$ & $63.8(62.9-64.6)$ \\
\hline Male & $5,872(32.3)$ & $62.7(61.5-63.9)$ \\
\hline \multicolumn{3}{|l|}{ Age (years) } \\
\hline $16-20$ & $1,690(9.2)$ & $57.2(54.8-59.6)$ \\
\hline $21-30$ & $5,029(27.6)$ & $65.4(64.1-66.7)$ \\
\hline $31-40$ & $4,633(25.4)$ & $65.0(63.6-66.4)$ \\
\hline $41-50$ & $3,151(17.3)$ & $64.7(63.0-66.3)$ \\
\hline $51-60$ & $2,046(11.2)$ & $63.7(61.6-65.7)$ \\
\hline$>60$ & $1,692(9.3)$ & $56.5(54.1-58.8)$ \\
\hline \multicolumn{3}{|l|}{ Ethnicity } \\
\hline White & $7,548(41.5)$ & $62.8(61.7-63.9)$ \\
\hline Non-white & $10,628(58.5)$ & $63.9(62.9-64.8)$ \\
\hline \multicolumn{3}{|l|}{ Socioeconomic } \\
\hline \multicolumn{3}{|l|}{ Household income } \\
\hline Low (< EUR 178.00) & $2,633(20.4)$ & $61.9(60.1-63.8)$ \\
\hline Middle (EUR 178.00 < 356.00) & $9,242(71.5)$ & $63.2(62.2-64.2)$ \\
\hline High (> EUR 356.00) & $1,043(8.1)$ & $65.9(63.1-68.8)$ \\
\hline \multicolumn{3}{|l|}{ Education } \\
\hline Illiterate & $242(1.4)$ & $56.2(49.9-62.4)$ \\
\hline Literate & $3,397(18.8)$ & $57.6(56.0-59.3)$ \\
\hline 9 years of schooling & $4,804(26.6)$ & $61.8(60.4-63.1)$ \\
\hline 12 years of schooling & $7,839(43.4)$ & $66.1(65.0-67.1)$ \\
\hline$\geq 16$ years of schooling & $1,775(9.8)$ & $69.4(67.3-71.6)$ \\
\hline \multicolumn{3}{|l|}{ Healthcare } \\
\hline \multicolumn{3}{|l|}{ FHT near residence } \\
\hline Yes & $10,125(57.7)$ & $58.3(57.3-59.2)$ \\
\hline No & $7,431(42.3)$ & $70.2(69.2-71.3)$ \\
\hline \multicolumn{3}{|l|}{ Case resolution } \\
\hline Demand resolved & $8,553(60.5)$ & $52.4(50.9-53.1)$ \\
\hline Partly resolved & $3,511(24.8)$ & $70.7(69.2-72.2)$ \\
\hline Not resolved & $2,083(14,7)$ & $82.6(81.0-84.3)$ \\
\hline \multicolumn{3}{|l|}{ Waiting time } \\
\hline 30 minutes & $5,074(36.3)$ & $50.7(49.3-52.1)$ \\
\hline 1 hour & $2,887(20.6)$ & $58.9(57.1-60.7)$ \\
\hline 4 hours & 4,881 (34.9) & $69.0(67.7-70.3)$ \\
\hline$>4$ hours & $1,149(8.2)$ & $78.8(76.5-81.2)$ \\
\hline
\end{tabular}

95\% Cl: 95\% confidence interval; FHT: family health team.

of schooling increases, individual expectations towards the services also increase, making it more difficult to meet such expectations. If older age and less schooling are important for public health satisfaction among users, this reinforces conformity to expectations on the one hand and calls for greater alignment with the interests of the younger and more educated population.

Another significant contextual variable for user dissatisfaction was the number of primary healthcare units per capita. More primary healthcare units contribute to better organization of 
Sample characteristics and mean dissatisfaction with Brazilian Unified National Health System (SUS), according to contextual variables, Brazil, 2012

\begin{tabular}{|c|c|c|c|}
\hline Dimension/Variables & Mean (SD) per individual & Mean (SD) per municipality & $\begin{array}{c}\text { Mean } \\
\text { dissatisfaction } \\
\text { (SD) }\end{array}$ \\
\hline \multicolumn{4}{|l|}{ Public health structure } \\
\hline Health establishments & $0.77(0.31)$ & $0.75(0.3)$ & $0.76(0.30)$ \\
\hline Primary healthcare units & $10.19(5.78)$ & $12.22(6.67)$ & $10.06(5.78)$ \\
\hline SUS establishments (\%) & $25.96(14.51)$ & $31.47(18.26)$ & $26.15(14.53)$ \\
\hline \multicolumn{4}{|l|}{ Family health coverage } \\
\hline $\mathrm{CHW}$ coverage $(\%)$ & $49.6(27.7)$ & $60.28(31.15)$ & $49.57(27.50)$ \\
\hline FHT coverage (\%) & $39.76(25.02)$ & $47.66(28.22)$ & $39.98(25.10)$ \\
\hline DHT coverage (\%) & $19.44(21.56)$ & $27.39(27.71)$ & $19.61(21.58)$ \\
\hline \multicolumn{4}{|l|}{ Outcomes of SUS } \\
\hline Life expectancy at birth & $70.16(2.34)$ & $69.48(2.96)$ & $70.07(2.29)$ \\
\hline Infant mortality rate & $13.7(2.96)$ & $14.7(3.59)$ & $13.78(2.96)$ \\
\hline SUS Performance Index & $5.65(0.71)$ & $5.52(0.77)$ & $5.61(0.72)$ \\
\hline \multicolumn{4}{|l|}{ Demographic structure } \\
\hline Population density & $2,397.02(2,512.05)$ & $1,901.69(2,340.19)$ & $2,460.07(2,507.32)$ \\
\hline \multicolumn{4}{|c|}{ Public investment in social area } \\
\hline Schools & $0.77(0.17)$ & $0.85(0.27)$ & $0.77(0.17)$ \\
\hline Literacy rate & $87.23(3.25)$ & $85.17(5.35)$ & $87.20(3.24)$ \\
\hline \multicolumn{4}{|l|}{ Economic conditios } \\
\hline Per capita income & 1,843.39 (787.15) & $1,666.08(769.54)$ & $1,804.69$ (778.93) \\
\hline Poverty rate & $31.68(14.01)$ & $36.07(14.88)$ & $32.42(14.08)$ \\
\hline \multicolumn{4}{|l|}{ Level of development } \\
\hline Gini & $0.45(0.04)$ & $0.45(0.04)$ & $0.449(0.04)$ \\
\hline HDI & $0.81(0.04)$ & $0.79(0.05)$ & $0.806(0.04)$ \\
\hline
\end{tabular}

CHW: community health workers; DHT: dental health teams; FHT: family health teams; HDI: Human Development Index.

care by meeting the demand, ensuring coverage in the municipality and guaranteeing that health teams can care for fewer users, who they get to know and with whom they develop routine and interpersonal relationships, responding efficiently to users' needs and expectations. Other studies have already confirmed the relationship between user satisfaction and internal work processes that are more efficient, accessible, appropriately located, and user-friendly 11,17,21,22,23, an association corroborated by the current study. This finding emphasizes the importance of maintaining investment in the construction of new health units and the concern for ensuring better infrastructure for health services in Brazil as a strategy for the construction, expansion, and renovation of primary healthcare units, funded jointly by the SUS and municipalities in a scheme called Requalifica-UBS (Re-qualification of primary healthcare units) 24 .
While user satisfaction can be understood as a result of the individual's accumulated experience 20 , the fact that users with resolved demand have lower dissatisfaction supports the importance of perception of a service's utility and resolution, both reported as factors that are highly valued by users. High prevalence of resolved demands also helps build trust and increase users' bond in their first experience with public health services, especially in primary healthcare 23 . Surprisingly, most participants in the current study were assisted by a FHT near their homes, which in turn was related to user satisfaction. The job profile of FHT is more suitable to the population's needs, and the services are more accessible, since the teams are organized to work in the area in which the users live; both factor were identified with satisfaction with health services. This relationship supports the relevance of the investment Brazil has made in expanding the FHS 5. 
Table 3

Crude and adjusted odds ratios (OR) for dissatisfaction with Brazilian Unified National Health System (SUS), according to individual and contextual variables, in the SUS-Satisfaction Study, Brazil, 2012.

\begin{tabular}{|c|c|c|}
\hline Level/Variables & Crude OR $(95 \% \mathrm{Cl})$ & Adjust OR $(95 \% \mathrm{Cl})$ \\
\hline \multicolumn{3}{|l|}{ Social structure * } \\
\hline Population density & $1.033(0.996-1.072) * \star$ & $1.031(0.999-1.065)^{\star \star \star}$ \\
\hline Schools & $1.107(0.736-1.665)$ & $1.015(0.624-1.650)$ \\
\hline Literacy rate & $0.998(0.977-1.019)$ & $1.074(1.032-1.118) * * *$ \\
\hline Per capita income & $0.845(0.758-0.942) * \star$ & $0.886(0.786-0.999) * * *$ \\
\hline Poverty rate & $1.009(1.003-1.015) * \star$ & $1.007(0.999-1.014)^{\star \star \star *}$ \\
\hline Gini & $1.014(0.992-1.036)$ & $1.012(0.992-1.032)$ \\
\hline $\mathrm{HDI}$ & $0.981(0.962-0.999) * \star$ & $0.952(0.916-0.988) * \star *$ \\
\hline \multicolumn{3}{|l|}{ Social context \# } \\
\hline Healthcare establishments & $0.611(0.464-0.804) * \star$ & $0.928(0.592-1.445)$ \\
\hline Primary healthcare units & $0.988(0.974-1.002) * \star$ & $0.979(0.959-0.999) * \star \star$ \\
\hline SUS establishments (\%) & $1.001(0.996-1.007)$ & $1.001(0.991-1.012)$ \\
\hline CHW coverage (\%) & $0.999(0.996-1.002)$ & $0.997(0.992-1.002)$ \\
\hline FHT coverage (\%) & $1.000(0.997-1.004)$ & $1.006(0.995-1.013)^{\star \star \star}$ \\
\hline DHT coverage (\%) & $1.000(0.996-1.004)$ & $1.000(0.993-1.006)$ \\
\hline Life expectancy at birth & $0.965(0.933-0.999) * \star$ & $0.983(0.932-1.037)$ \\
\hline Infant mortality rate & $1.011(0.983-1.039)$ & $0.981(0.945-1.020)$ \\
\hline SUS performance index & $0.830(0.740-0.930) \star \star$ & 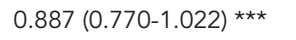 \\
\hline \multicolumn{3}{|l|}{ Individual demographic characteristics \#\# } \\
\hline Gender (male vs. female) & $0.985(0.923-1.052)$ & $0.978(0.916-1.046)$ \\
\hline Age (16-20 vs. $>60$ years $)$ & $1.075(0.934-1.237)$ & $1.087(0.942-1.253)^{\star \star \star}$ \\
\hline Age $(21-30$ vs. $>60$ years $)$ & $1.534(1.365-1.724) * \star$ & $1.567(1.392-1.764) * \star *$ \\
\hline Age (31-40 vs. $>60$ years) & $1.498(1.332-1.684) \star \star$ & 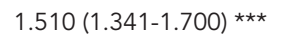 \\
\hline Age (41-50 vs. $>60$ years) & $1.429(1.263-1.616) \star \star$ & 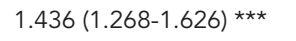 \\
\hline Age (51-60 vs. $>60$ years) & $1.357(1.187-1.551) \star \star$ & 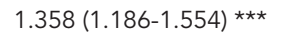 \\
\hline Ethnicity (white vs. non-white) & $1.048(0.981-1.119) * \star$ & 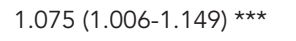 \\
\hline \multicolumn{3}{|l|}{ Individual health services characteristics \#\#\# } \\
\hline Household income (middle vs. low) & $1.096(1.001-1.201) \star \star$ & $1.077(0.963-1.205)$ \\
\hline Household income (high vs. low) & $1.283(1.100-1.496)$ ** & $1.198(0.951-1.508)$ \\
\hline Education (literate vs. illiterate) & $1.081(0.829-1.411)$ & $0.933(0.642-1.357)$ \\
\hline Education ( 9 years vs. illiterate) & $1.270(0.976-1.654)$ ** & $1.136(0.781-1.654)$ \\
\hline Education (12 years vs. illiterate) & 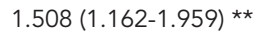 & $1.202(0.826-1.749)$ \\
\hline Education ( $\geq 16$ years vs. illiterate) & $1.842(1.397-2.430) \star \star$ & $1.493(0.977-2.280)$ \\
\hline FHS near residence (no vs. yes) & $1.678(1.571-1.791) \star \star$ & 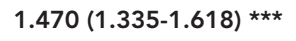 \\
\hline Solution (not resolved vs. resolved) & $4.429(3.919-5.005)$ ** & $3.659(3.134-4.272) * \star \star$ \\
\hline Solution (partly resolved vs. resolved) & $2.230(2.049-2.428) * \star$ & $1.926(1.728-2.146)$ \\
\hline Waiting time ( $1 \mathrm{~h}$ vs. $30 \mathrm{~min})$. & $1.411(1.285-1.549) * *$ & $1.301(1.154-1.466)$ \\
\hline Waiting time (4h vs. $30 \mathrm{~min})$. & $2.185(2.011-2.375)$ ** & $1.862(1.673-2.073)$ \\
\hline Waiting time (> $4 \mathrm{~h}$ vs. $30 \mathrm{~min})$. & $3.599(3.086-4.197)$ ** & $2.825(2.328-3.427) * \star \star$ \\
\hline
\end{tabular}

95\% Cl: 95\% confidence interval; CHW: community health workers; DHT: dental health teams; FHT: family health teams.

* Adjusted OR were obtained inserting all the variables from this level in the model.

** p-value $<0.20$

*** $p$-value $<0.20$ within level in each block. These variables remained in the models for all the next levels;

\# Adjusted OR were obtained inserting all the variables from this level in the model, plus the variables with p-value $<0.20$ in the first level;

\#\# Adjusted OR were obtained inserting all the variables from this level in the model, plus the variables with $p$-value $<0.20$ in the first and second levels:

\#\# Adjusted OR were obtained inserting all the variables from this level in the model, plus the variables with $p$-value $<0.20$ in the first, second, and third levels.

Note: bold values are significant at the $5 \%(p$-value $<0.05)$. 
Waiting time between arrival at the healthcare unit and first contact with a health professional was strongly related to satisfaction with the SUS. This is a consistent finding in Brazilian and international studies on user satisfaction 22,25 and thus emphasizes the importance of health teams organizing their internal work process, access to innovative technologies, and creation of healthcare agendas in order to ensure that users do not have to wait more than 30 minutes for their first contact with health professionals.

An unexpected result was the limited impact of FHT coverage on user satisfaction with the SUS, although treatment by a FHT near home was an important predictor. Other Brazilian studies have shown that FHT were able to structure their internal work process to the point of providing timely care with better case-resolution and suitability for demands. The FHS has achieved significant levels of deployment, covering more than half of the Brazilian population, improving health indicators, and reducing infant mortality and hospitalizations due to primary caresensitive conditions, thus proving the strategy's effectiveness in overcoming inequities 5,6,7,8,26. The literature associating the FHS with high user satisfaction corroborates the view that a resident in a municipality with high FHS coverage would be more satisfied with the services, but this study showed that experience with personal service and user characteristics are more important in determining satisfaction 18 .

These municipalities have other primary care services called Traditional Health Teams that are not classified as FHT. This network of care has become more cohesive and homogeneous since the Ministry of Health published the new National Primary Care Policy 8 ensuring access, quality of care, and links to the population. In this study, such teams were included not in the variable on FHT coverage, but rather in the variable on number of primary healthcare units per capita.

Another question that has received little attention in the literature is the relationship between context and user satisfaction. The association with variables that are not strictly related to the healthcare system sheds light on the debate concerning inter-sector effects. If the social determinants of health are not tackled properly, this challenges the more linear interpretation that public policies in health, interventions in the structure and process, and administrative development are sufficient to decrease the population's dissatisfaction with the SUS.

Some limitations are important when interpreting the study's results, including recall bias and the study design, since users were asked about experiences with the services that oc- curred within one year before the survey (reverse temporality can occur in cross-sectional studies). In addition, some authors consider user satisfaction a layperson's opinion, thus not as accurate as a technically qualified assessment of health services 21,23 . However, it is vital to consider the profusion of robust and relevant information generated by this study in order to better understand health system users' expectations and criticisms.

The inclusion of municipalities with less than 500,000 inhabitants should be regarded with caution. Unlike other municipalities (state capitals and municipalities with more than 500,000 inhabitants), in which a census was performed, a simple random sample of small municipalities was necessary due to the large number of these cities, which means that the municipalities with less than 500,000 inhabitants included in this study do not represent all the municipalities of this strata in Brazil.

The observed prevalence of dissatisfaction may also be affected by the computer-mediated telephone interview technique. Since users responded independently, the possibility of being treated worse at their next appointment would tend not to be a concern, and thus they would not feel pressured to offer a more positive assessment. High prevalence of satisfaction often occurs in studies where the researcher is a member of the healthcare team and the interview takes place at the clinic or healthcare service, emphasizing the asymmetry of power relations between users and the healthcare team and thereby attenuating criticism by participants. In addition, since part of the telephone number database used for the sample came from the ombudsman's office, the study sample could conceivably include a higher proportion of disgruntled users than in the user population in general 20,23,27.

\section{Conclusions}

The methodology used here allowed analyzing an extensive list of independent contextual and individual variables, thus representing a considerable step ahead of the initial analysis of satisfaction surveys on health, which are mostly related to a SUS. Characteristics of health teams, and especially their internal work process, are clearly essential dimensions for evaluation in this research area. It is thus essential to monitor user satisfaction systematically and periodically, comparing the results and establishing new guidelines for government action and policies to meet the population's expectations. 


\section{Contributors}

L. G. Passero, J. M. A. Giordani, F. N. Hugo, and J. B. Hilgert contributed to the conception, methodology, analysis, revision, and final written version. V. B. L. Torman and S. A. Camey collaborated in the methodology, analysis, and revision of the article.

\section{Acknowledgments}

The authors wish to thank the Department of Primary Care of the Brazilian Ministry of Health.

\section{References}

1. Presidência da República, Casa Civil. Lei no 8.080, de 19 de setembro de 1990. Dispõe sobre as condições para a promoção, proteção e recuperação da saúde, a organização e o funcionamento dos serviços correspondentes e dá outras providências. Diário Oficial da União 1990; 20 set.

2. Presidência da República, Casa Civil. Lei no 8.142 de 28 de dezembro de 1990. Dispõe sobre a participação da comunidade na gestão do Sistema Único de Saúde (SUS) e sobre as transferências intergovernamentais de recursos financeiros na área da saúde e dá outras providências. Diário Oficial da União 1990; 31 dez.
3. Gerschman S. Conselhos Municipais de Saúde: atuação e representação das comunidades populares. Cad Saúde Pública 2004; 20:1670-81.

4. Paim J, Travassos C, Almeida C, Bahia L, Macinko J. The Brazilian health system: history, advances, and challenges. Lancet 2011; 377:1778-97.

5. Departamento de Atenção Básica, Secretaria de Atenção à Saúde, Ministério da Saúde. Política Nacional de Atenção Básica. Brasília: Ministério da Saúde; 2012. (Série E. Legislação em Saúde). 
6. Guanais FC, Macinko J. Primary care and avoidable hospitalizations: evidence from Brazil. J Ambul Care Manage 2009; 32:115-22.

7. Macinko J, Guanais FC, Souza MFM. Evaluation of the impact of the Family Health Program on infant mortality in Brazil, 1990-2002. J Epidemiol Community Health 2006; 60:13-9.

8. Macinko J, Souza MFM, Guanais FC, Simões CCS. Going to scale with community-based primary care: an analysis of the family health program and infant mortality in Brazil, 1999-2004. Soc Sci Med 2007; 65:2070-80.

9. Silva RCC, Pedroso MC, Zucchi P. Ombudsmen in health care: case study of a municipal health ombudsman in health care: case study of a municipal health ombudsman. Rev Saúde Pública 2014 48:134-41.

10. Departamento de Ouvidoria Geral do SUS, Secretaria de Gestão Estratégica e Participativa, Ministério da Saúde. Orientações para implantação de ouvidorias do SUS. Brasília: Ministério da Saúde; 2006. (Série B. Textos Básicos de Saúde).

11. Sixma HJ, Spreeuwenberg PMM, van der Pasch MAA. Satisfaction with the general practitioner - a two level analysis. Med Care 1998; 36:212-29.

12. Baron-Epel O, Dushenat M, Friedman N. Evaluation of the consumer model: relationship between patient 's expectations, perception and satisfaction with care. Int J Qual Health Care 2001; 13:317-23.

13. Bernhart MH, Wiadnyana IGP, Wihardjo H, Pohan I. Patient satisfaction in developing countries. Soc Sci Med 1999; 48:989-96.

14. Andersen RM. Revisiting the behavioral model and access to medical care: does it matter? J Health Soc Behav 1995; 36:1-10.

15. Victora CG, Huttly SR, Fuchs SC, Olinto MT. The role of conceptual frameworks in epidemiological analysis: a hierarchical approach. Int J Epidemiol 1997; 26:224-7.

16. Snijders TAB, Bosker RJ. Multilevel analysis: an introduction to basic and advanced multilevel modeling. London/Thousand Oaks: Sage Publications; 1999.

17. Wadhwa SS. Customer satisfaction and health care delivery systems: commentary with Australian bias. The Internet Journal of Health 2002; 3:1-7.

18. al-Qatari G, Haran D. Determinants of users' satisfaction with primary health care setting and services in Saudi Arabia. Int J Qual Health Care 1999; 11:523-31
19. Zastowny TR, Roghmann KJ, Cafferata GL. Patient satisfaction and the use of health services: exploration in causality. Med Care 1989; 27:705-23.

20. Espiridião M, Trad LAB. Avaliação de satisfação de usuários: considerações teórico-conceituais. Cad Saúde Pública 2006; 22:1267-76.

21. Wilkinson RG, Marmot M. Social determinants of health: the solid facts. $2^{\text {nd }}$ Ed. Copenhagen: World Health Organization; 2003.

22. Fitzpatrick R, Hopkins A. Problems in the conceptual framework of patient satisfaction research: an empirical exploration. Sociol Health Illn 1983; 5:297-311.

23. Atkinson SJ. Anthropology in research on the quality of health services. Cad Saúde Pública 1993; 9:283-99.

24. Ministério da Saúde. Portaria GM/MS no 340, de 4 de março de 2013, que altera a Portaria no 648/ GM/MS, de 28 de março de 2006, na parte que Redefine o Componente Construção do Programa de Requalificação de Unidades Básicas de Saúde (UBS). Diário Oficial da União 2013; 5 mar.

25. Gouveia GC, Souza WV, Luna CF, Souza Júnior PRB, Szwarcwald CL. Health care users' satisfaction in Brazil, 2003. Cad Saúde Pública 2005; 21 Suppl:S109-18.

26. Fachini LA, Piccini RX, Tomasi E, Thumé E, Silveira DS, Siqueira FV, et al. Desempenho do PSF no Sul e no Nordeste do Brasil: avaliação institucional e epidemiológica da Atenção Básica à Saúde. Ciênc Saúde Coletiva 2006; 11:669-81.

27. Merhy EE. Ato de cuidar: alma dos serviços de saúde. In: Merhy EE, organizador. Saúde: a cartografia do trabalho vivo. Apêndice 1. São Paulo: Editora Hucitec; 2002. p. 115-33. 


\section{Resumo}

Sabe-se que a satisfação do usuário relaciona-se com a qualidade em saúde. O objetivo foi avaliar a influência de fatores contextuais e individuais associados a insatisfação do usuário com o Sistema Único de Saúde (SUS). Este é um estudo transversal multinível. Os dados foram coletados pela ouvidoria através de contato telefônico. Números de telefone foram selecionados aleatoriamente de um banco de dados de empresas de telefonia. Foram avaliadas variáveis de serviço de saúde, socioeconômicas e demográficas individuais, bem como informações dos municípios. O desfecho foi insatisfação com o SUS. Regressão logística multinível foi utilizada, com uma abordagem hierárquica. 18.673 indivíduos foram contatados. A prevalência de insatisfação foi 63,4\% (IC95\%: 62,7-64,1). Demanda não resolvida $(O R=3,66)$, espera $>4$ horas $(O R=2,82) e$ número de unidades básicas de saúde $(O R=0,89)$ estiveram associados à insatisfação. Características do processo de trabalho das equipes de saúde foram fortemente associadas à insatisfação.

Análise Multinível; Comportamento do Consumidor; Serviços de Saúde

\section{Resumen}

Se sabe que la satisfacción del usuario se relaciona con la calidad en salud. El objetivo fue evaluar la influencia de factores contextuales e individuales asociados a la insatisfacción del usuario con el Sistema Único de Salud brasileño (SUS). Este es un estudio transversal multinivel. Los datos fueron recogidos por una auditoría a través de contacto telefónico. Se seleccionaron los números de teléfono aleatoriamente de un banco de datos de empresas de telefonía. Se evaluaron variables de servicio de salud, socioeconómicas y demográficas individuales, así como información de los municipios. El resultado fue insatisfactorio en relación con el SUS. Se utilizó la regresión logística multinivel, con un en foque jerárquico. 18.673 individuos fueron contactados. La prevalencia de insatisfacción fue de un $63,4 \%$ (IC95\%: 62,7-64,1). La demanda no resuelta $(O R=$ $3,66)$, espera $>4$ horas $(O R=2,82)$ y número de unidades básicas de salud $(O R=0,89)$ estuvieron asociados a la insatisfacción. Características del proceso de trabajo de los equipos de salud estuvieron fuertemente asociadas a la insatisfacción.

Análisis Multinivel; Comportamiento del

Consumidor; Servicios de Salud
Submitted on 22/Apr/2015

Final version resubmitted on 23/Sep/2015

Approved on 24/Oct/2015 